\title{
Response to Chester Gillis
}

\section{Sr. Amata Miller, I.H.M.}

I'm a development economist, meaning that I often spend time explaining to people how the system works in terms of those for whom it doesn't work. So the only thing I would add to what Dr. Gillis has said about the importance of interreligious dialogue is the fact that data from both scholars and activists of economic development around the world address what I consider to be the most critical moral obscenity of our time: the existence of abysmal poverty for so many of our brothers and sisters in this world, both in our country and in the rest of the world, alongside of dramatic abundance.

If we're going to make a difference in this world, the most important thing is to educate women. ${ }^{\mathrm{I}}$ And so the education of women of all faiths is absolutely critical. Bringing

1. It is commonly accepted among specialists in economic and social development that education of women is critical for the building up of what economists call the "human capital" essential for the economic development of societies. Many studies document that educating the women leads to improved health, rising standards of living, better nutrition, and a greater return on investments than public investment in infrastructure. The history of microfinance organizations indicates that extending the access to credit for women yields more economic improvement for families than similar extensions of credit to men. See Michael P. Todaro and Stephen C. Smith, Economic Development, 10th Edition (Boston: Pearson/Addison-Wesley, 2009), p. 22: "In light of the information presented so far it should come as no surprise that development scholars generally view women as playing the central role in the development drama ... To make the biggest impact on development, then, a society must employer and invest in its women." See also Nicholas D. Kristof and Sheryl WuDunn, Half The Sky: Turning Oppression Into Opportunity for Women Worldwide (New York, N.Y.: Alfred A. Knopf, 2009), pp. xix-xxi, which include statements from the United Nations Development Programme, Doctors Without Borders, the Center for Global Development, UNICEF, and the World Bank about the

Amata Miller, I.H.M. is a professor of economics at St. Catherine University, director of the school's Myser Initiative on Catholic Identity, and holds the Archbishop Harry Flynn Distinguished Chair in Catholic Identity. Additionally, she teaches in the Master of Social Justice program at Marygrove College, and is a member of the Global Economic Justice Workshop Team of the Partnership for Global Justice in New York City. For six years, she was the Education Coordinator and Economic Analyst at NETWORK: A National Catholic Social Justice Lobby in Washington, D.C. She has served as trustee or director of many institutions including St. Edwards University, Marygrove College, Mercy Housing, Partners for the Common Good, NETWORK, Catholic Health Initiatives, Catholic Health Audit Network, Shorebank, and Mary's Pence. 
women to our campuses in ways that enable them to experience the contributions that a Catholic identity can bring in terms of an expanded world view-a world view which is less individualistic, less narcissistic, and more socially minded-is a critical gift of our Catholic identity. In my response, then, I will share about how another Catholic college, which comes from a different religious congregation, with a different kind of a charism, has welcomed people who are religiously diverse.

\section{St. Catherine University}

St. Catherine University was founded in I905 as the College of St. Catherine in St. Paul, Minnesota, which was then the Wild West, and was radically founded as a women's college by the Sisters of St. Joseph of Carondelet, who had come by steamboat up the Mississippi and tramped their way through the snow up the hill to where the campus is now. The foundation of the college was under the leadership of Mother Seraphine Ireland, who was the provincial of the Sisters of St. Joseph, and the sister of the indomitable John Ireland, archbishop of St. Paul.

The Sisters of St. Joseph had been founded at the time of the French Revolution by a group of six women, including their leader Jeanne Fontbonne, under the guidance of Jean Pierre Medaille, S.J. ${ }^{2}$ As with Jesuit institutions, our mission is rooted in the charism of the founding religious congregation, whose charism is "loving the dear neighbor without distinction." Some years ago, the Sisters of St. Joseph College Consortium, which then represented twelve colleges, set out to identify the characteristics through which their institutions carried out this charism. The first one was hospitality and a caring community. The second one was concern for all without distinction. We have, therefore, had diverse populations from the very beginning. Hospitality and welcoming the religiously other are fundamental to the mission and the spirit of Josephite colleges, as is the spirit of social responsibility and academic excellence.

The university now has two-year programs, which are co-ed, and graduate programs that are co-ed, while its undergraduate program is exclusively for women. We say in our mission statement that we have a women's college at our heart. Our women's college enrolls the largest number of women of any of the sixty-five women's colleges in the country, more than any of the Ivies.

Our mission has three key elements. We are a Catholic college. We are rooted in Catholic traditions of intellectual inquiry and social teaching. We are rooted in the liberal arts and in the spirit of women's pedagogy. Our university is recognized by accreditors and by visitors as especially a mission-directed institution, because our mission is very clear about what we aim to do and how we do it. And we do what we say we are going to do.

The question is how well we are welcoming the religiously other at St. Kate's (as we call it). According to the history of the school, the Sisters welcomed women of all

importance of gender equality in education and in development. "'Investment in girls' education may well be the highest-return investment avalable in the developing world, Lawrence Summers wrote when he was chief economist of the World Bank" (p. xx).

2. See a brief history of the order on their website, http://www.coseph.org/our_heritage.aspx. faiths from the very beginning. In the very beginning, the religiously other were a small number, but today only about forty percent of our undergraduates declare themselves as Catholic. And an increasing number, about thirty-five percent, don't declare any faith at all. We suspect that there are some Catholics among them, or some disaffected women Catholics who are probably the most difficult group to deal with on our campus in terms of Catholic identity.

We have a religiously diverse college for women and one that is rooted in our Catholic identity and in our heritage, with those emphases of the habits of intellectual inquiry, the liberal arts, and social justice tradition. In the beginning, there were many Irish immigrants who came to the St. Paul area to work on the railroads. Today, the Twin Cities have attracted large groups of Hmong people from Laos, as well as a sizeable community of Somali Muslims who have settled in Minneapolis. The Hmong come from a patriarchal tribal culture and are mainly animists, although there are a few Christians among them.

\section{Welcoming the Religiously Other}

St. Kate's has responded to the challenge of educating the young women of these groups. Assisted by a foundation grant a few years ago, the university prepared special videos in various languages, featuring staff people and students from those cultures. The videos helped to educate the parents about the importance of higher education for their daughters, and to help overcome some of the obstacles of their entering college. We now have a critical mass of Hmong students among our undergraduates. We have over two hundred of them, and they are active in student government. And we have a growing number of Somali women on our two campuses. Two years ago, a Somali woman got the highest of our prizes for student leadership.

Campus ministry has a special prayer room now for Muslim women. The Muslim student association is one of the strongest student clubs on campus, and it provides support for our Muslim students, but it also provides many different kinds of events to educate the other students about Muslim customs and Muslim culture. We see increasing numbers, as do many of your campuses, of veiled Muslim students of all various persuasions of Muslim culture, mingling with their non-Muslim friends and their roommates, evidences of growing relationships and mutual understanding. One of the theology professors told me the other day that in his basic theology class, he had a Muslim student who had a Latina roommate who dragged her along to the class so that they could both learn together. This kind of interreligious collaboration is growing dramatically, as have the service organizations that help the students adjust to campus life.

The Abigail Quigley McCarthy Women's Center on campus has become a welcoming place for both Hmong and Muslim students. They have found there a special place to work and study between classes. A Hmong staff member who is a St. Kate's graduate herself provides understanding and encouragement to the students who are struggling with the realities of literally living between two cultures, living in two cultures. She works to help them help one another deal with those challenges, as well as the challenges of 
being in college and holding jobs to finance that education. She has been instrumental in the founding of a student-led group called Hmong Daughters, and the story of this organization was featured in one of the publications of the American Association of University Women recently. It fosters a community-based approach to women's leadership development and helps to develop a network of community engagement among these young women.

One of the group's guidelines is "don't leave your life at the door." In other words, they are encouraged to share the challenges that they experience within the totality of their life together. They eat lunch together at periodic times, sharing their culture and their foods with the Muslim students and other students, and they build support for one another in all of this together. They are also developing together the skills of transformational leadership, which women from both the Hmong and Somali cultures must learn to embrace. This transformation is no small task for education.

\section{Curriculum}

Dean Gillis has described what the theology department at Georgetown does. Ours, of course, is much smaller, but we offer an increasing number of courses in world religions. Our first course is called Theological Questions, and that's the required course for students. But the increasing number of courses in world religions (Judaism, Islam, Hinduism, and Buddhism) brings leaders—rabbis and leaders of these faiths—-to assist with the teaching.

Our graduate program in theology, which is about twenty years old now, offers a specialization in world spiritualities. We have a spiritual direction component, the only Catholic university between Loyola in Chicago and Creighton in Nebraska that has this kind of a certificate. We have attracted men and women of all faiths to this program over the years.

In our undergraduate college, we have two core courses that are taken by every student. Every entering student takes a course called The Reflective Woman, where we explore what it means to be a college student. Students share about their different ethnic backgrounds in classes, which are also their orientation groups. The second unit is about different approaches to truth, where students get in touch with the basic scope of the liberal arts and the different ways of knowing. The third unit is about what it means to be a woman in community. The capstone course is called Global Search for Justice, where they bring together all the insights from their various majors together with the call to be women who foster justice around the world. Those courses are increasingly taught in other countries. For both courses, we have specially designed readers that are revised every two years by the faculty, and in both of those courses, welcoming the other is stressed. This welcome is on many levels: race, gender, culture, and religion. In teaching about social responsibility, readings from Martin Luther King Jr., Gandhi, and the Universal Declaration of Human Rights are always included along with those on Catholic social teaching.

\section{Meaningful Conversations}

In the 2012 elections, Minnesota voters were asked to vote on an amendment to the state constitution regarding same-sex marriages. Our archbishop was very active in that effort. At the time, same-sex marriages were already prohibited by state law and the amendment was defeated. ${ }^{3}$ But to prepare the students for this vote, we told the archbishop that we could not advocate one position. Our role as universities is to prepare our students to understand the various perspectives on this aspect of faith. And so, to prepare our students, we had an interfaith panel with a representative of the Minnesota Catholic Conference, a Jewish rabbi, and a Lutheran ethicist. (Minneapolis is Lutheran and St. Paul is Catholic, so we have many Lutheran students.) We also sponsored two sessions on the respectful conversations process, and that was a process that was developed by the Protestant group, the Minnesota Council of Churches, to help their congregations deal with the complexity of perspectives on this key issue.

In order to help foster a deeper understanding of, respect for, and appreciation of the Catholic identity among the faculty, who will then work through the curriculum to permeate its spirit throughout the educational process, we sponsor an annual small group, weeklong stipended faculty workshop each summer. Small voluntary groups of fifteen to twenty faculty members are introduced to the Catholic principles of the intellectual tradition and social teaching, and they spend time working on various projects to incorporate the principles into their courses and curriculum. Interdisciplinary faculty come together, people from many different faiths-we have Catholics, we have angry former Catholics, we have those who are married to Catholics and don't understand their spouse, we have agnostics in the group. I remember one woman came and she said, "How negative can I be?" I said, "You can be as negative as you need to be." And she entered into the group fully and became transformed in her ability to understand Catholic faith and those of others.

The work of the spirit never ceases to amaze me. We've done this six times now, heading for the seventh one. This type of engaging with one another in meaningful conversations is the approach that we have taken at our university to infusing what we do with Catholic identity. Rather than have a vice-president for mission, the president herself is the mission officer of the institution, and she has raised endowments to foster within the faculty each of the three elements of the mission of the university, and we start from the bottom up with the belief that the best way to knit this into the fabric of the institution is to infuse the faculty itself, the people who will be there for a long time, with the spirit of these elements of our mission.

And so, what we have found is that beginning with meaningful conversations about faith issues is gradually infusing campus life with welcoming hospitality in the spirit of our Catholic tradition. These examples show how St. Kate's is engaging in the four fold activities of interfaith dialogue that are pointed out by the Vietnamese-American

3. The state prohibition on same-sex marriage was later repealed, and the first same-sex marriages were performed in August, 2013 
theologian Peter Phan. First, dialogue of life, a neighborly exchange of daily joys, problems, and concerns. Second, a dialogue of action, collaboration in projects of mutual interest. Third, a dialogue of religious experience, sharing spiritual practices. And finally, a dialogue of theological exchange, where specialists undertake to enrich each other's conception of their respective religions and spiritual traditions. ${ }^{4}$

4. Peter Phan, "Praying to the Buddha: Living Amid Religious Pluralism," Commonweal (Jan. 26, 2007), pp. 11-12. 